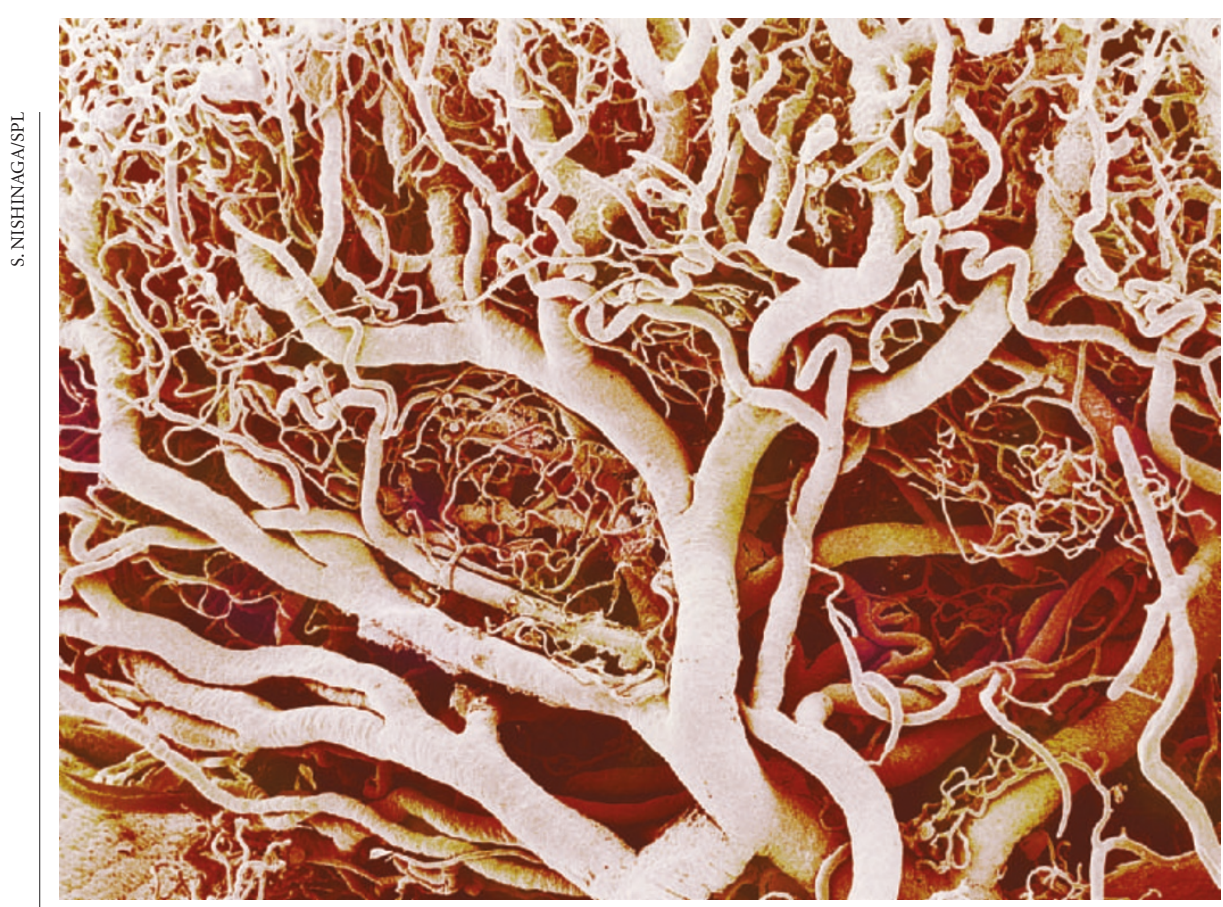

Branching out: a 'sandpit' exercise on blood-vessel formation led to some innovative research projects.

\title{
Sandpit initiative digs deep to bring disciplines together
}

Jim Giles, Dundee

A British research agency is trying out a fresh approach to creating interdisciplinary projects. It throws researchers from different fields into a 'sandpit' for a week with the promise of $\mathfrak{E} 1$ million (US\$1.8 million) in support for the best ideas to come out of it.

The Engineering and Physical Sciences Research Council (EPSRC) tried out the concept for the first time in Dundee, Scotland, last month — and participants pronounced it an instant success. The topic was angiogenesis — the formation of new blood vessels - and the outcome was two proposed collaborations that the agency says it is likely to support.

The exercise wasn't without its pitfalls, however, as researchers struggled to get inside one another's heads. "I just don't understand the language they use," sighed Ana Schor, a cell biologist at the University of Dundee, after hearing a talk by a mathematician.

Although multidisciplinary workshops are commonplace, EPSRC officials say that their allocation of $£ 1$ million to support proposals from the sandpit was a new departure, which they hope to build on. "It worked," says John King, a mathematician at the University of Nottingham who helped to organize the meeting. "I'd like to see the approach applied to funding other subjects."

About 40 mathematicians, engineers, biologists, clinicians and others attended the session, and differences between their use of terminology and methodology surfaced early on. Mathematicians, for example, complained that the biologists wanted to build models containing too many variables, whereas the biologists were frustrated at what they saw as the mathematicians' inability to explain clearly just what their models could achieve.

Some discussions went round in circles for hours as participants failed to settle on an aspect of the problem that could hold everybody's attention. "The social dynamics are as interesting as the science," says Oliver Jensen, an applied mathematician at the University of Nottingham. When proposals for grants did start to emerge, tensions rose again as different ideas competed for the prize on offer.

Two of these eventually won out. Researchers from Imperial College London and the universities of Nottingham, Oxford and Dundee are expected to get $\mathfrak{E 6 0 0 , 0 0 0}$ to develop a kind of three-dimensional Petri dish. The dish will be used to examine how molecules involved in blood-vessel formation cause cells to release other compounds, for example, and to migrate. In the long term, they hope to simulate the formation of complete blood vessels in the device.

Another project, led by Christopher Mitchell, an expert in angiogenesis at the University of Nottingham, is set to get

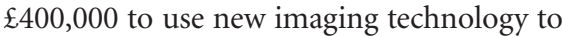
observe the formation of blood vessels in live mice. Both projects are expected to be funded after formal peer review.

"The meeting certainly generated ideas," says Robert Keatch, a microengineer from the University of Dundee. "It was more intense than a conference because we had to come up with a research proposal in five days."

\section{Ethics accusations spark rapid reaction from NIH chief}

Erika Check, Washington

The US National Institutes of Health (NIH) will act immediately to address concerns that its ethics standards are not rigorous enough, its director, Elias Zerhouni, has told Congress. But lifesciences lobbyists are already worried that the ethics issue is hurting the agency's budget outlook for 2005.

Concerns about ethics at the NIH were raised last month in the Los Angeles Times (see Nature 426, 741; 2003). The newspaper alleged that some of the agency's employees have been inappropriately influenced by consulting arrangements that were deliberately shielded from public view.

Billy Tauzin (Republican, Louisiana), chair of the energy and commerce committee in the House of Representatives, which oversees the NIH, had given Zerhouni until 8 January to respond to the allegations.

In letter sent in response to Tauzin, Zerhouni outlined a four-point action plan to address the concerns. He said that the NIH will review all external payments received by its employees since 1999 . He also pledged to set up an ethics advisory committee inside the agency, as well as an outside panel of experts to advise the NIH on its ethics policies and practices. Finally, he pledged to review the policies that dictate when and how NIH employees disclose their consulting relationships to the public, and to "act to increase appropriate financial disclosure".

"Our mission is too important to the public health of the Nation to have it undermined by any real or perceived conflicts of interest," Zerhouni wrote.

Additionally, on 5 January, the NIH issued rules pertaining to conflicts of interest among scientists who serve on its scientific review panels. The rules largely articulate existing practice, observers of the agency say, and are not expected to make much difference to researchers who review NIH grant applications.

Officials at scientific societies praised Zerhouni's rapid response to the criticism. But they say that the issue has come at an awkward time for the agency, which faces an uphill fight for funding this year. President George Bush is expected to propose an increase of about $2 \%$ in the NIH's \$27-billion budget when he sets out his 2005 budget early next month - much less than the agency has enjoyed in recent years. 